\title{
In vitro anti-Onchocerca ochengi activities of extracts and chromatographic fractions of Craterispermum laurinum and Morinda lucida
}

\author{
Moses Samje ${ }^{1,2}$, Jonathan Metuge ${ }^{2}$, James Mbah ${ }^{3}$, Brice Nguesson ${ }^{3}$ and Fidelis Cho-Ngwa ${ }^{2^{*}}$
}

\begin{abstract}
Background: Onchocerciasis caused by Onchocerca volvulus is the world's second leading infectious cause of blindness. There is currently no cure for the disease. Ivermectin, the current drug of choice is only microfilaricidal and suboptimal response to it is increasingly being reported. Thus, in contributing to the search for a cure, crude extracts and chromatographic fractions of Craterispermum laurinum and Morinda lucida were screened in vitro, against the bovine and most popular model of the parasite, Onchocerca ochengi.
\end{abstract}

Methods: Extracted parasites were cultured in RPMI-1640 based media for 05 days in the presence of control drugs, test drugs or drug diluents only. Microfilarial motility was scored using microscopy while adult worm viability was determined biochemically by MTT/formazan colorimetry. Cytotoxicity and acute toxicity of active fractions were tested on monkey kidney epithelial cells (LLCMK2) and in Balb/c mice, respectively.

Results: Out of the 18 extracts screened, the methanolic extracts of the leaves of both plants recorded the highest activities against both the microfilariae ( $\left(\mathrm{C}_{100}\right.$ of $125 \mu \mathrm{g} / \mathrm{ml}$ for both extracts) and adult worms $\left(\mathrm{IC}_{100}\right.$ of $250 \mu \mathrm{g} / \mathrm{ml}$ and $500 \mathrm{\mu g} / \mathrm{ml}$ for $\mathrm{M}$. lucida and C. laurinum respectively). The most active chromatographic fraction was obtained from M. lucida and had an $\mathrm{IC}_{50}$ of $7.8 \mu \mathrm{g} / \mathrm{ml}$ and $15.63 \mu \mathrm{g} / \mathrm{ml}$ on microfilariae and adult worms respectively, while the most active fraction from C. laurinum had an $\mathrm{IC}_{50}$ of $15.63 \mu \mathrm{g} / \mathrm{ml}$ and $46.8 \mu \mathrm{g} / \mathrm{ml}$, respectively on microfilariae and adult worms. The $50 \%$ cytotoxic concentration $\left(C_{50 s}\right.$ ) on LLCMK2 cells ranged from $15.625 \mu \mathrm{g} / \mathrm{ml}$ to $125 \mu \mathrm{g} / \mathrm{ml}$ for the active fractions. No acute toxicity was recorded for the extracts from both plants. Phytochemical analysis of the most active fractions revealed the presence of sterols, alkaloids, triterpenes, saponins and flavonoids.

Conclusions: This study validates the use of these plants by traditional health practitioners in managing the disease, and also suggests a new source for isolation of potential lead compounds against Onchocerca volvulus.

Keywords: Onchocerciasis, Medicinal plants, Toxicity, Phytochemical analysis

\section{Background}

Human onchocerciasis (river blindness) caused by the filarial worm, Onchocerca volvulus is one of the neglected tropical diseases of major public health concerns [1]. The disease is the world's second leading infectious cause of blindness with over 37 million patients and a risk population of over 120 million [2]. Hyper endemic villages can have infection rates of close to $100 \%$, where up to $10 \%$ of an entire village may be blind due to the disease. Close to

\footnotetext{
* Correspondence: fidelis.ngwa@fulbrightmail.org

${ }^{2}$ Department of Biochemistry and Molecular Biology, Faculty of Science, University of Buea, P.O. Box 63, Buea, Cameroon

Full list of author information is available at the end of the article
}

99\% of all patients live in Tropical Africa [3,4]. Pathologically, the disease is associated with extensive and disfiguring skin changes, musculoskeletal complaints, weight loss, and changes in the immune system [5]. In addition to its severe pathological effect, it causes grave socio-economic problems and life-long human suffering [6].

Two major strategies employed in the control of onchocerciasis are mass treatment of infected people with ivermectin and the elimination of the Simulium vector $[7,8]$. Despite the successes registered in reducing the disease burden, total elimination has not been achieved due to pitfalls in the control programmes. At present, only ivermectin (Mectizan ${ }^{\circ}$, Merck) is recommended for 
chemotherapy and for mass drug administration. Although this drug has been shown to significantly reduce transmission of the disease, its filaricidal effect is limited only on the juvenile form of the parasite $[9,10]$. Studies have revealed that treatment of some Onchocerca patients with ivermectin who are co-infected with Loa loa may result in adverse effects, which ranged from fatigue to consciousness disorders and death $[11,12]$. Therefore, the ideal drug for onchocerciasis would be inactive against the microfilariae of Loa loa. Suboptimal response to ivermectin has also been reported in different studies [13-16]. Thus, the search for new, safe and efficacious onchocerciasis drugs is imperative.

Herbal medications play a central role in the cure of several diseases particularly in developing countries $[17,18]$. In some Asian and African countries, $80 \%$ of the population depends on traditional medicine for primary health care, and herbal medicines are the most lucrative form of traditional medicine, generating billions of dollars in revenue [19]. The anti-filarial activities of some plant extracts have been documented [20-23]. M. lucida and C. laurinum (family: Rubiaceae) have been shown to express antibacterial activity on a range of bacteria [24,25]. Other separate studies have revealed that $M$. lucida possess anti-plasmodial activity [26], suppressed Trypanosoma brucei parasites [27] and have hypoglycaemic activity [28]. Onchocerca ochengi, found exclusively in cow is the closest relative to the medically important $O$. volvulus. Similarities lie in them sharing the same vector, their microfilariae being equally sensitive to ivermectin and their adult worms found in the sub-cutaneous/intradermal nodules [29]. Since the bovine parasite species is relatively more abundant in Africa and also cheap to obtain, it is thus a model of choice in anti-onchocercal drug screens. In an attempt to contribute to anti-onchocercal lead development, we herein report on in vitro filaricidal properties of both crude extracts and chromatographic fractions of extracts of C. laurinum and M. lucida against Onchocerca ochengi parasite stages. Additionally, we report on the cyto- and acute toxicity profiles of the best extracts and fractions of the two plants, thereby initiating a novel lead compound discovery endeavour.

\section{Methods}

\section{Collection and identification of plant materials}

Various plant parts (leaves, barks and roots) of C. laurinum were collected from Finge village of the Bambui Health District in the North West Region of Cameroon in June 2010, while M. lucida plant parts were collected from Buea at the foot of Mount Fako, Cameroon in January 2011. The plants were selected based on ethnopharmacological information about them. The plants were identified and authenticated by Mr. Paul Mezili of the National Herbarium, Yaounde, Cameroon and given the voucher number (Poir) Benth No 3781/SRFK for C. laurinum and Benth No 2615/SRFK for M. lucida. Locally, C. laurinum is called "sarkaatari".

\section{Preparation of crude extracts and chromatographic fractions}

All the plant parts collected were air dried, then ground to fine powder. The ground materials were weighed and sequentially submerged and macerated for a total of 72 hours in three solvents thus: hexane (HEX), methylene chloride $(\mathrm{MC})$, and methanol $(\mathrm{MeOH})$. For each solvent, the maceration was repeated twice. The mixture was filtered and the filtrate concentrated using a rotary evaporator (BUCHI Rotavapor R-200, Switzerland) at appropriate temperatures. The concentrate were recovered with methylene chloride and allowed to stand open at room temperature until all the residual solvents had evaporated. The dried crude extracts were stored at $-20^{\circ} \mathrm{C}$ until needed for the assays.

Bioassay-guided fractionation was done on the most active crude extracts. Each of the latter extract was fixed on celite and fractionated using vacuum liquid chromatography on silica gel and then eluted with a continuous gradient of ethyl acetate (EtOAc [0-80\%]) in hexane, followed with a gradient of methanol $(\mathrm{MeOH}[0-40 \%])$ in methylene chloride. Collected fractions were pooled on the basis of their thin layer chromatographic (TLC) profiles.

\section{Isolation and culture of 0 . ochengi adult worms (macrofilariae)}

This was done by the method of Cho-Ngwa et al. [22] with slight modifications. Briefly, fresh pieces of umbilical cattle skin containing large amount of palpable nodules were brought from local slaughterhouses to the laboratory. The skin was thoroughly washed successively with tap and distilled water, drained and totally covered with $70 \%$ ethanol which was allowed to evaporate on its own in a laminar flow hood sterile environment. Pale orange-yellow $O$. ochengi adult worm masses containing essentially viable adult female and male worms were recovered by careful dissection of the nodules using sterile razor blade. The extracted worms were immediately submerged into complete culture medium (CCM) (RPMI1640 supplemented with $25 \mathrm{mM}$ HEPES, $2 \mathrm{~g} / \mathrm{L}$ sodium bicarbonate, $20 \mathrm{mM} \mathrm{L}$-glutamine, $10 \%$ new born calf serum [SIGMA, USA], 200 units $/ \mathrm{ml}$ penicillin, $200 \mu \mathrm{g} / \mathrm{ml}$ streptomycin and $2.5 \mu \mathrm{g} / \mathrm{ml}$ amphotericin B [Sigma, USA], $\mathrm{pH}$ 7.4) in 24 wells. The viability of worms was determined by microscopic examination using an inverted microscope (euromex, Holland). The cultures were incubated at $37^{\circ} \mathrm{C}$ under an atmosphere of $5 \% \mathrm{CO}_{2}$ in humidified air in a HERACELL-150 $\mathrm{CO}_{2}$ incubator (Thermo Electron, Germany) for 05 days post addition of drug. 


\section{Extraction of microfilariae}

Fresh and cleaned infected cattle skin was sterilized as above and tautly attached onto a sterile wooden board. A portion of the skin was then carefully shaved with razor blade, rinsed with distilled water and completely covered with $70 \%$ ethanol. The ethanol was allowed to evaporate freely and completely in a laminar flow hood. The skin was then firmly attached onto an autoclaved cylindrical piece of wood and close crisscross cuts of about $0.5-1 \mathrm{~mm}$ apart were made into the epidermal and dermal layers, over the entire skin surface. The entire assembly was transferred into a sterilized glass cylinder and an appropriate volume of CCM was added to just cover the entire skin. The assembly was incubated for $4-$ 6 hours at room temperature. The emergent and highly motile microfilariae $(\mathrm{mfs})$ were concentrated by centrifugation (400 $\times g$ for 10 minutes) and quantified microscopically. Then, $100 \mu \mathrm{l}$ of CCM containing $15-20 \mathrm{mfs}$ was transferred into each well of a 96 well microtitre culture plates. After addition of drugs, the $\mathrm{mfs}$ were cultured at $37^{\circ} \mathrm{C}$ under an atmosphere of $5 \% \mathrm{CO}_{2}$ in humidified air in a HERACELL-150 $\mathrm{CO}_{2}$ incubator (Thermo Electron, Germany).

\section{Preparation of mammalian cells for microfilarial cultures and cytotoxicity assay}

Monkey kidney epithelial cells (LLCMK2) purchased from the American Type Culture Collection (ATCC, Virginia, USA) was proliferated in complete culture media at $37^{\circ} \mathrm{C}$ and $5 \% \mathrm{CO}_{2}$. Once the cells became fully confluent, the old media was decanted and the cells were dislodged with $0.125 \%$ trypsin and $0.5 \mathrm{mM}$ EDTA in serum-free RPMI-1640 culture medium. The dislodged cells were re-suspended in $10 \mathrm{~mL}$ of complete culture medium and centrifuged at $560 \times \mathrm{g}$ for 10 minutes to get rid of the trypsin. The last procedure was repeated once. The cell suspension $(100 \mu \mathrm{L} /$ well $)$ was transferred into 96-well microtitre culture plates and kept in the $\mathrm{CO}_{2}$ incubator for cells to grow and become fully confluent, usually taking 3-5 days depending on the initial concentration of cells. LLCMK2 cells served as feeder layer for mfs cultures and also for cytotoxicity studies. The selectivity index (SI) of each extract was calculated as the ratio of $\mathrm{CC}_{50}$ of drug to these mammalian cells to the $\mathrm{IC}_{50}$ of the drug on the parasites.

\section{Preparation and in vitro screening of crude extracts and fractions}

A stock solution of $25 \mathrm{mg} / \mathrm{ml}$ crude extract in $\geq 99.9 \%$ sterile dimethyl sulfoxide (SIGMA, USA) was prepared. Adult worm assays were conducted in 24-well plates (2 mL/well) (NUNC, USA) for 5 days without any change of medium. On the other hand, all mfs-only assays were conducted in 96-well microtitre plates $(200 \mu \mathrm{L}$ /well) that contained confluent feeder layer of the monkey kidney cells. The media used in preparing the feeder cell layer was removed by swift decantation before fresh medium and worms for drug testing were added. Assays were run for 5 days post-addition of extract without any change of medium.

\section{Primary screen for adult worm and microfilariae}

This was done in order to eliminate inactive extracts. Each extract was dissolved to $2 \mathrm{X}$ its final test concentration in CCM in a single sterile well before distribution into replicate wells. In this regard, $1 \mathrm{ml}$ per well or $100 \mu \mathrm{l}$ per well for adult worm or mfs respectively, were transferred into replicate culture wells, each already containing either adult worm in $1 \mathrm{ml}$ of CCM or $\mathrm{mfs}$ in $100 \mu \mathrm{l}$ of CCM, to give a final volume of either $2 \mathrm{ml}$ for the adult worm assay or $200 \mu \mathrm{l}$ for the mfs assay. The crude extracts were tested in quadruplicate wells (for adult worms) and in duplicate (for $\mathrm{mfs}$ ) at a single concentration of $500 \mu \mathrm{g} / \mathrm{mL}$. A compound (BTU55261) known to be active (unpublished) was used as the positive control for the adult worm assay, while ivermectin (IVM) was used as a positive control for the $\mathrm{mfs}$ assay. BTU55261 produces $100 \%$ inhibition of formazan formation in adult worms on day 5 at a concentration of $2.5 \mu \mathrm{g} / \mathrm{ml}$, while IVM totally inhibits mfs motility at $10 \mu \mathrm{g} / \mathrm{ml}$ by day 5 . Negative controls were treated in the same way as the test samples, received the drug diluents $(\leq 2 \%$ DMSO in RPMI), but with no drug added.

Male worm motility inhibition was scored using an inverted microscope and was recorded as $100 \%$ (complete inhibition), $75 \%$ (only head or tail of worm moving or vibrating), $50 \%$ (worm sluggish) or $25 \%$ (little change in motility), $0 \%$ (no observable inhibition of motility). Biochemical evaluation of adult worm viability was done using the MTT/formazan colorimetric assay [30,31]. The worms were placed under sterile conditions in a well of a 48-well plate containing $500 \mu \mathrm{L} /$ well of $0.5 \mathrm{mg} / \mathrm{mL}$ MTT (Sigma, USA) in serum free media and then incubated under the culture conditions for 30 minutes. Thereafter, the worms were blotted individually on tissue paper and colour development of the test compared with the controls. MTT, a pale yellow compound is reduced to a dark blue product, formazan by the living cells of the worms. Adult worm viability was taken as mean percent inhibition of formazan formation relative to negative control at 120 hours post addition of drug. Inhibition of formazan formation by extracts relative to the negative controls showed that an extract was either active $(90 \%$ or greater mean inhibition of formazan formation), moderately active (50 - 89\% mean inhibition of formazan formation) or inactive ( $<50 \%$ mean inhibition of formazan formation). Viability of mfs was assessed by reading their mean motility scores every 24 hours (post addition of drug) for 
120 hours on the same scale as for adult male worms. An extract was considered active on the $\mathrm{mf}$ if there was a $100 \%$ reduction in $\mathrm{mfs}$ motility; moderately active if there was a 50-99\% mean reduction in mfs motility and inactive if there was less than $50 \%$ mean inhibition of motility compared to untreated controls of the same experiment.

\section{Secondary screen}

This was done in order to confirm the activity of extracts that were promising in the primary screen, as well as to determine the $\mathrm{IC}_{50}$ and selectivity index (SI) values. All the active extracts that showed $100 \%$ macrofilaricidal and/ or microfilaricidal properties were re-tested as in the primary screens and at serial dilutions of 8 different concentrations starting from $500 \mu \mathrm{g} / \mathrm{mL}$ down to $3.91 \mu \mathrm{g} / \mathrm{mL}$. The graphical analysis was done using Microsoft Excel 2007 (Microsoft Corporation, USA).

\section{Acute toxicity of active extracts in mice}

The test was conducted following the European Community Guidelines for protection of animals used for experimental purposes [32] and respecting the 3Rs (Replacement, Refinement and Reduction) of Animals in Research [33]. Currently, there is no law governing the use of $\mathrm{Balb} / \mathrm{C}$ mice for research purposes in Cameroon. Mice used in the study were commercially gotten from Centre Pasteur, Yaoundé. Nulliparous, non-pregnant 10 weeks old female Balb/c mice were weighing $22.4 \pm 1.5 \mathrm{~g}$ were randomly selected and kept in their cages for 5 days before dosing [34]. The test was done for the methanolic extracts of C. laurinum and M. lucida as well as for fractions that demonstrated an $\mathrm{IC}_{50}$ of $\leq 31.25 \mu \mathrm{g} / \mathrm{ml}$ on $\mathrm{mfs}$. The equivalent of 5 times $\mathrm{IC}_{50}$ of each substance was injected intraperitoneally into separate groups of 6 mice while 6 control mice were injected with an equal volume of diluent (2\% DMSO in normal saline). Briefly, considering the $5 \times \mathrm{IC}_{50 \text { s }}$ of $93.75 \mu \mathrm{g} / \mathrm{ml}$ for the C. laurinum extract, $10.3 \mathrm{mg}$ of the extract was dissolved in 100\% DMSO and then diluted in normal saline such that the final DMSO concentration was $2 \%$. The diluted extract was then injected into the chosen mice. The same procedure was repeated for all the selected active fractions. Following dosing, the animals were observed every 30 minutes for the first 4 hours. Thereafter, the physical activity, weight of food and the volume of water consumed, changes in skin and fur, tremors, convulsions, diarrhea, sleep, coma and death were noted daily for the 14 day study period.

\section{Phytochemical analysis}

Following screening, phytochemical derivatives found in the most active fractions were investigated by standard methods [35]. Briefly, the presence of alkaloid was determined using the Drangedoff's reagent while the presence of sterols and triterpenes was determined by the Liebermann
Buchard reaction. For the presence of flavonoids, the extract was dissolved in methanol and $2-3 \mathrm{~mL}$ of concentrated $\mathrm{HCl}$ was added. A spatula full of magnesium turnings was then added and the mixture observed for effervescence. The presence of saponins was determined by dissolving a trace amount of the extract in water and shaking thoroughly. Frothing which persisted on warming was observed and taken as preliminary evidence. Test for Tanins was done by adding $10 \mathrm{ml}$ of distilled water to $2 \mathrm{~g}$ of plant extract, stirred, filtered and ferric chloride later added to the filtrate.

\section{Results}

Activity of crude extracts of both plants on adult worm and microfilariae

A total of 18 crude extracts were prepared from the two plants (9 from each) using solvents of different polarities (hexane, methylene chloride and methanol). Results of the primary screen showed that the methanol extracts of the leaves of both plants had the highest anti-parasite activity. By contrast, the methanol extracts of barks, roots, as well as the hexane extracts and methylene chloride extracts of both plants were inactive. Consequently, further testing on these extracts was discontinued. Table 1 summarizes the effect of the methanolic extracts of both plants on adult worm and $\mathrm{mfs}$.

The SIs of $\mathrm{CL}_{\mathrm{LMeOH}}$ and $\mathrm{ML}_{\mathrm{LMeOH}}$ on adult male and female worms was 1 while those of $\mathrm{CL}_{\mathrm{LMeOH}}$ and $\mathrm{ML}_{\mathrm{LMeOH}}$ on $\mathrm{mf}$ were respectively 2.6 and 2 and that of ivermectin in the same experiment was 1.0. This was not surprising since ivermectin kills Onchocerca $\mathrm{mfs}$ in vitro within 5 days only at a much higher concentration relative to the therapeutic dose in humans. Although there was $100 \%$ inhibition of mfs motility on day 5 for extracts of both plants at $125 \mu \mathrm{g} / \mathrm{ml}$, M. lucida demonstrated more rapid activity in time-dependent studies (Figure 1). Complete inhibition of motility was observed with $M$. lucida by the 48 th hour unlike C. laurinum which showed full activity only at the 120th hour.

\section{Activity of chromatographic fractions of C. Iaurinum on microfilariae and adult worms}

Nine fractions; A, B, C, D, E, F, G, H, I were sequentially obtained and tested on both the juvenile and adult form of the parasite. The first and last fractions (A and I) were inactive on both the $\mathrm{mfs}$ and adult worms. The highest activity on $\mathrm{mfs}\left(\mathrm{IC}_{100}\right.$ of $31.25 \mu \mathrm{g} / \mathrm{ml}$ and $\mathrm{IC}_{50}$ of $15.625 \mu \mathrm{g} / \mathrm{ml}$ ) was observed with fraction $\mathrm{G}$ (Table 2). Except for fractions $B$ and $H$, there was $100 \%$ inhibition of mfs motility by the 24th hour of culture in the presence of the active fractions at the highest concentration of $500 \mu \mathrm{g} / \mathrm{ml}$. Four fractions (A, B, H and I) showed no activity on the adult female worms. Out of 
Table 1 Dose-dependent effect of crude extracts of $C$. Iaurinum and M. Iucida on male and female adult worms and microfilariae

\begin{tabular}{|c|c|c|c|c|c|c|}
\hline \multirow[t]{2}{*}{$\begin{array}{l}\text { Concentration of } \\
\text { extract }(\mu \mathrm{g} / \mathrm{mL})\end{array}$} & \multicolumn{2}{|c|}{$\begin{array}{l}\% \text { inhibition of adult male } \\
\text { worm motility }\end{array}$} & \multicolumn{2}{|c|}{$\begin{array}{l}\% \text { inhibition of formazan formation } \\
\text { by female worm }\end{array}$} & \multicolumn{2}{|c|}{$\begin{array}{l}\% \text { inhibition of } \\
\text { mfs motility }\end{array}$} \\
\hline & $\mathrm{CL}_{\mathrm{LMeOH}}$ & $\mathrm{ML}_{\mathrm{LMeOH}}$ & $\mathrm{CL}_{\mathrm{LMeOH}}$ & $\mathrm{ML}_{\mathrm{LMeOH}}$ & $\mathrm{CL}_{\mathrm{LMeOH}}$ & $\mathrm{ML}_{\mathrm{LMeOH}}$ \\
\hline 500 & 100 & 100 & 100 & 100 & 100 & 100 \\
\hline 250 & 50 & 100 & 50 & 100 & 100 & 100 \\
\hline 125 & 50 & 50 & 50 & 50 & 100 & 100 \\
\hline 62.5 & 0 & 0 & 0 & 0 & 25 & 50 \\
\hline 31.25 & 0 & 0 & 0 & 0 & 0 & 25 \\
\hline 15.63 & 0 & 0 & 0 & 0 & 0 & 0 \\
\hline 0 & 0 & 0 & 0 & 0 & 0 & 0 \\
\hline Positive control & 100 & 100 & 100 & 100 & 100 & 100 \\
\hline Negative control & 0 & 0 & 0 & 0 & 0 & 0 \\
\hline
\end{tabular}

(CL $\mathrm{LMeOH}_{\text {: }}$ methanolic extract of $C$. laurinum and $\mathrm{ML}_{\mathrm{LMeOH}}$ : methanolic extract of M. lucida).

these, Fraction $\mathrm{H}$ demonstrated moderate activity on the adult male worms while the rest were inactive on the male worms. Fraction E inhibited motility and formazan formation in the male adult and female adult worms respectively at the same concentration (Figure 2 $\mathrm{a}$ and $\mathrm{b})$. A comparison of the $\mathrm{IC}_{50 \mathrm{~s}}$ of the adult worms and $\mathrm{mfs}$ and the $\mathrm{CC}_{50 \mathrm{~s}}$ of the most active fractions is shown in Figure 3.

Activity of chromatographic fractions from the methanol extract of $M$. lucida on microfilariae and adult worms

One hundred and fifty fractions of $500 \mathrm{~mL}$ each were collected using hexane:ethyl acetate and methylene chloride: methanol eluent. The fractions were pooled on the basis of their TLC profiles to give a total of seventeen combined fractions (MLM 1 - 17). Out of these 17, four of them showed moderate activity on $\mathrm{mfs}$ but were inactive on either the adult male or female worms while the rest exhibited full activity on $\mathrm{mfs}$ at a concentration of $500 \mu \mathrm{g} / \mathrm{ml}$ by day 5. The dose-dependent result of the active fractions on $\mathrm{mfs}$ by the 120th hour of culture is shown on Table 3. Fraction MLM10 was the most active with an $\mathrm{IC}_{100}$ of $15.63 \mu \mathrm{g} / \mathrm{ml}$ and an $\mathrm{IC}_{50}$ of $7.8 \mu \mathrm{g} / \mathrm{ml}$. Additionally, the fractions also exhibited a time dependent inhibition of $\mathrm{mfs}$ and adult male motility. Out of the 17 fractions, seven showed activity on the adult worms (Figure $4 \mathrm{a}$ and b) while 5 were moderately active. Only two of the seven active extracts exhibited effect on both the male and female worms at the same concentration. The general trend observed for the seven most active fractions was that they were all almost more active on the male adult worms and $\mathrm{mfs}$ than their adult female counterpart (Figure 5). Figure 6

C. laurinum $\mathbf{D}$ M. lucida

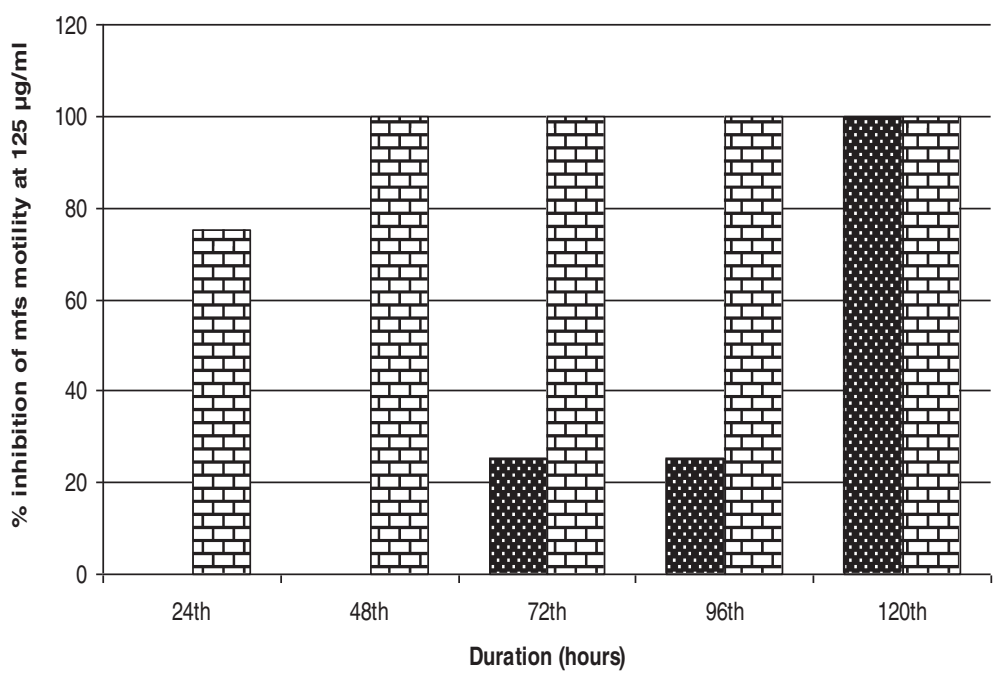

Figure 1 Time-dependent inhibition of $\mathrm{mfs}$ motility at $125 \mu \mathrm{g} / \mathrm{ml}$ by the methanolic extract of $M$. Iucida and $C$. Iaurinum. 
Table 2 Chromatographic profile and activity of nine fractions of $\mathrm{CL}_{\mathrm{LMeOH}}$ on microfilariae motility

\begin{tabular}{|c|c|c|c|c|c|c|c|c|c|c|}
\hline \multirow{2}{*}{$\begin{array}{l}\text { Eluent } \\
\text { Hex:EtOAC }\end{array}$} & \multirow{2}{*}{$\begin{array}{l}\text { Combined } \\
\text { Fractions: code }\end{array}$} & \multicolumn{8}{|c|}{$\%$ inhibition of microfilarial motility on day 5 concentration of extracts $(\mu \mathrm{g} / \mathrm{ml})$} & \multirow[b]{2}{*}{$\mathrm{IC}_{50}$ of $\mathrm{mfs}$} \\
\hline & & 500 & 250 & 125 & 62.5 & 31.25 & 15.63 & 7.8 & 0 & \\
\hline 100:0 & 1-14: A & 0 & 0 & 0 & 0 & 0 & 0 & 0 & 0 & / \\
\hline 90:10 & 15-20: B & 100 & 50 & 0 & 0 & 0 & 0 & 0 & 0 & 250 \\
\hline $80: 20$ & 21-28: C & 100 & 100 & 100 & 0 & 0 & 0 & 0 & 0 & 93.5 \\
\hline $70: 30$ & 29-39: D & 100 & 100 & 25 & 25 & 0 & 0 & 0 & 0 & 187.5 \\
\hline $60: 40$ & 40-60: E & 100 & 100 & 75 & 50 & 25 & 0 & 0 & 0 & 62.5 \\
\hline $40: 60$ & 61-67: F & 100 & 100 & 100 & 100 & 75 & 50 & 0 & 0 & 15.63 \\
\hline \multicolumn{11}{|c|}{$\mathrm{CH}_{2} \mathrm{Cl}_{2}: \mathrm{MeOH}$} \\
\hline $20: 80$ & 68-78: G & 100 & 100 & 100 & 100 & 100 & 50 & 0 & 0 & 15.63 \\
\hline $95: 5$ & 79-99: H & 100 & 75 & 50 & 25 & 0 & 0 & 0 & 0 & 125 \\
\hline $0: 100$ & 100-108: I & 0 & 0 & 0 & 0 & 0 & 0 & 0 & 0 & / \\
\hline
\end{tabular}

Hex: hexane, EtOAc: ethyl acetate, TLC: thin layer chromatography, $\mathrm{CH}_{2} \mathrm{Cl}_{2}$ : methylene chloride, $\mathrm{MeOH}$ : methanol.

a
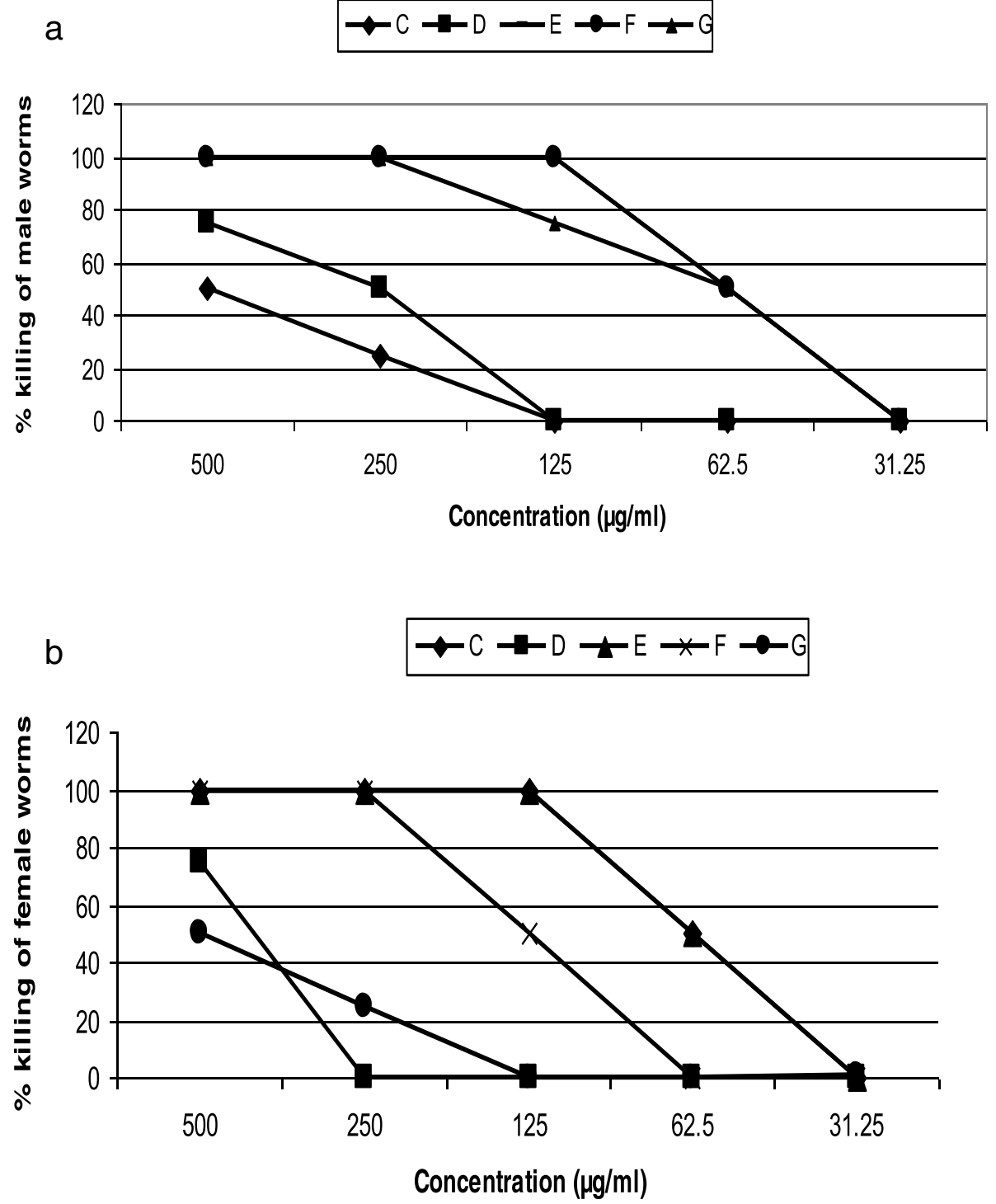

Figure 2 Percent killing of male adult worms (a) and female adult worms (b) by active fractions from C. laurinum. 


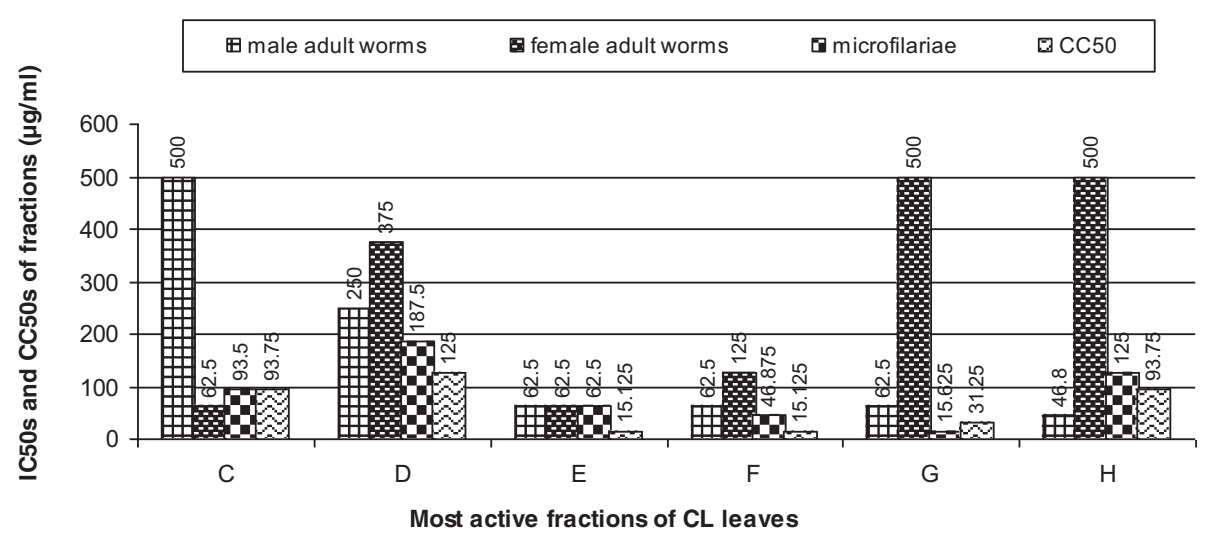

Figure $3 \mathrm{IC}_{50 \mathrm{~s}}$ and $\mathrm{CC}_{50 \mathrm{~s}}$ of most active fractions of C. laurinum on respectively mfs, adult worms and LLCMK2 cells.

shows a colored picture on the varying degree of killing of adult worms by fraction MLM11. This dose-dependent disparity in the conversion of MTT to formazan is a reflection of adult worm viability.

\section{Cytotoxicity and acute toxicity of active extracts}

Cytotoxicity was determined for all the crude extracts and chromatographic fractions, while acute toxicity was done only for the most active extracts and fractions. For the most active fractions of C. laurinum, the cytotoxic concentration of the fractions on LLCMK2 cells ranged from $15.125 \mu \mathrm{g} / \mathrm{ml}$ to $125 \mu \mathrm{g} / \mathrm{ml}$ (Figure 7a) while those of fractions from M. lucida ranged from $15.625 \mu \mathrm{g} / \mathrm{ml}$ to $31.25 \mu \mathrm{g} / \mathrm{ml}$ (Figure $7 \mathrm{~b}$ ). The $\mathrm{CC}_{50 \mathrm{~s}}$ of the active fractions for C. laurinum and $M$. lucida are respectively shown on Figures 3 and 5. The SIs of the two active

Table 3 Chromatographic profile and activity of seventeen fractions from $M_{L M e O H}$ on microfilariae motility

\begin{tabular}{|c|c|c|c|c|c|c|c|c|c|c|}
\hline \multirow{2}{*}{$\begin{array}{l}\text { Eluent } \\
\text { Hex:EtOAc }\end{array}$} & \multirow{2}{*}{$\begin{array}{l}\text { Combined } \\
\text { Fractions:code }\end{array}$} & \multicolumn{8}{|c|}{$\%$ inhibition of microfilariae motility on day 5 concentration of extracts $(\mu \mathrm{g} / \mathrm{ml})$} & \multirow[b]{2}{*}{$\mathrm{IC}_{50}$ of $\mathrm{mfs}$} \\
\hline & & 500 & 250 & 125 & 62.5 & 31.25 & 15.63 & 7.8 & 0 & \\
\hline $100: 0$ & 1-13: MLM1 & 100 & 50 & 0 & 0 & 0 & 0 & 0 & 0 & 250 \\
\hline \multirow[t]{2}{*}{ 95:5 } & 14-16: MLM2 & 50 & 0 & 0 & 0 & 0 & 0 & 0 & 0 & 500 \\
\hline & 17-24: MLM3 & 100 & 100 & 50 & 0 & 0 & 0 & 0 & 0 & 125 \\
\hline $90: 10$ & 25-32: MLM4 & 50 & 0 & 0 & 0 & 0 & 0 & 0 & 0 & 500 \\
\hline \multirow[t]{2}{*}{$80: 20$} & 33-40: MLM5 & 100 & 75 & 0 & 0 & 0 & 0 & 0 & 0 & 187.5 \\
\hline & 41-49: MLM6 & 50 & 25 & 0 & 0 & 0 & 0 & 0 & 0 & 500 \\
\hline \multirow[t]{2}{*}{$70: 30$} & 50-54: MLM7 & 100 & 75 & 50 & 0 & 0 & 0 & 0 & 0 & 125 \\
\hline & 55-61: MLM8 & 100 & 100 & 100 & 50 & 25 & 0 & 0 & 0 & 62.5 \\
\hline \multirow[t]{2}{*}{$60: 40$} & 62-65: MLM9 & 100 & 100 & 100 & 100 & 50 & 0 & 0 & 0 & 31.25 \\
\hline & 66-74: MLM10 & 100 & 100 & 100 & 100 & 100 & 100 & 50 & 0 & 7.8 \\
\hline $50: 50$ & 75-86: MLM11 & 100 & 100 & 100 & 100 & 50 & 50 & 25 & 0 & 15.63 \\
\hline $40: 60$ & 87-100:MLM12 & 100 & 100 & 100 & 50 & 0 & 0 & 0 & 0 & 62.5 \\
\hline \multirow[t]{2}{*}{$20: 80$} & 101-109:MLM13 & 100 & 100 & 100 & 100 & 100 & 25 & 0 & 0 & 23.44 \\
\hline & 110-117:MLM14 & 100 & 100 & 100 & 100 & 50 & 0 & 0 & 0 & 31.25 \\
\hline \multicolumn{11}{|c|}{$\mathrm{CH} 2 \mathrm{Cl} 2 \mathrm{MeOH}$} \\
\hline \multirow[t]{2}{*}{$95: 5$} & 118-120:MLM15 & 100 & 100 & 100 & 50 & 25 & 25 & 25 & 0 & 62.5 \\
\hline & 121-128:MLM16 & 75 & 50 & 25 & 0 & 0 & 0 & 0 & 0 & 250 \\
\hline $90: 10$ & 129-150:MLM17 & 100 & 50 & 0 & 0 & 0 & 0 & 0 & 0 & 250 \\
\hline \multicolumn{11}{|l|}{$80: 20$} \\
\hline \multicolumn{11}{|l|}{$70: 30$} \\
\hline $60: 40$ & & & & & & & & & & \\
\hline
\end{tabular}




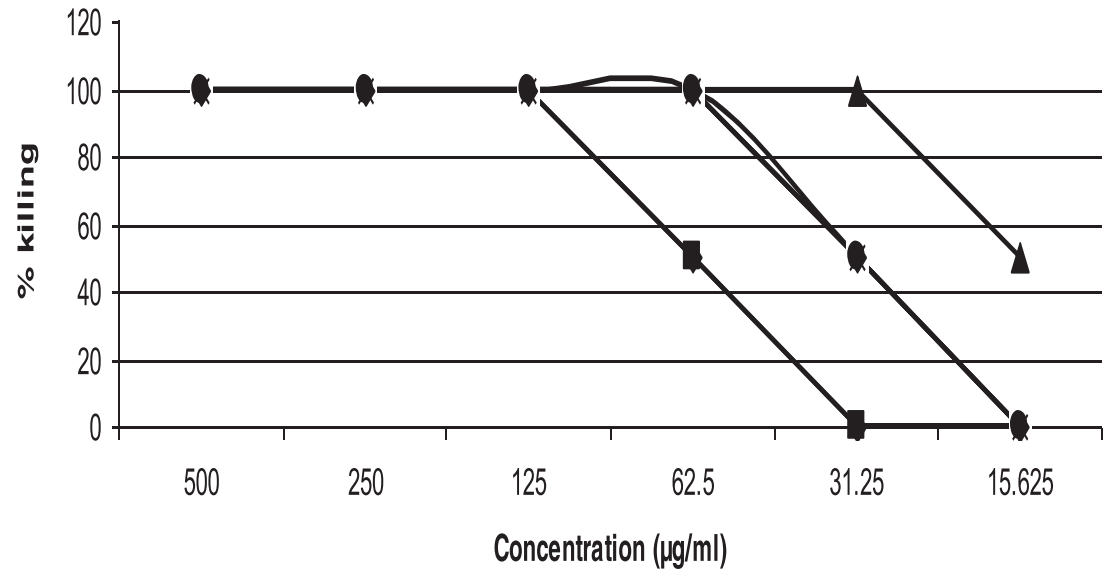

b
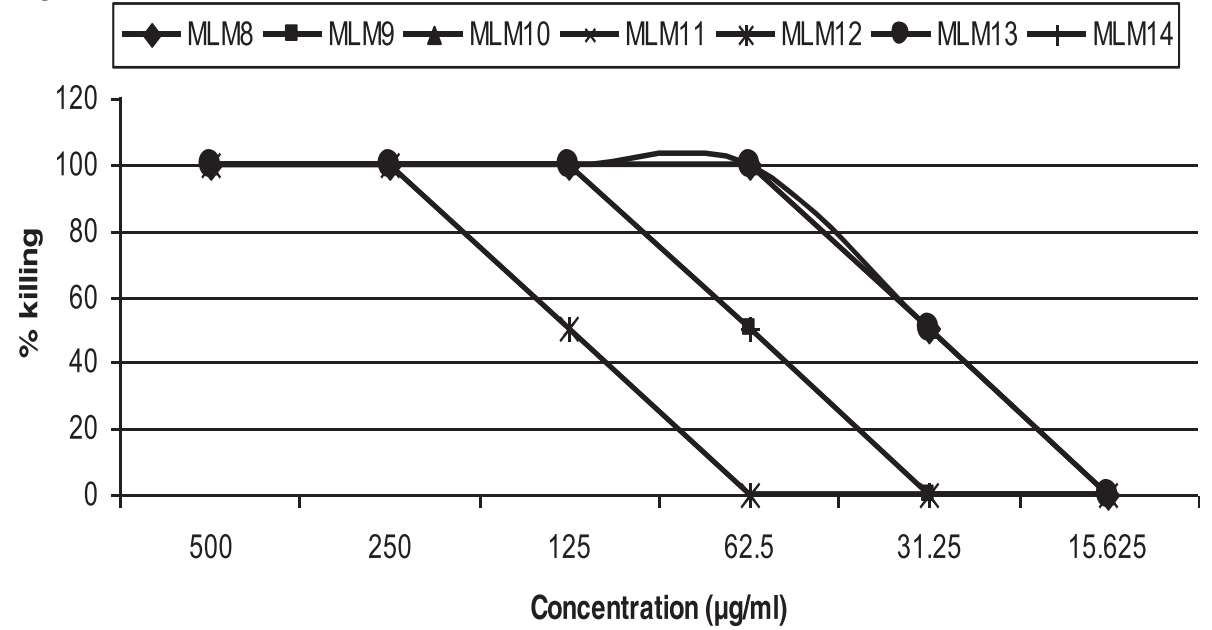

Figure 4 Percent killing of male adult worms (a) and female adult worms (b) by active fractions from M. lucida.

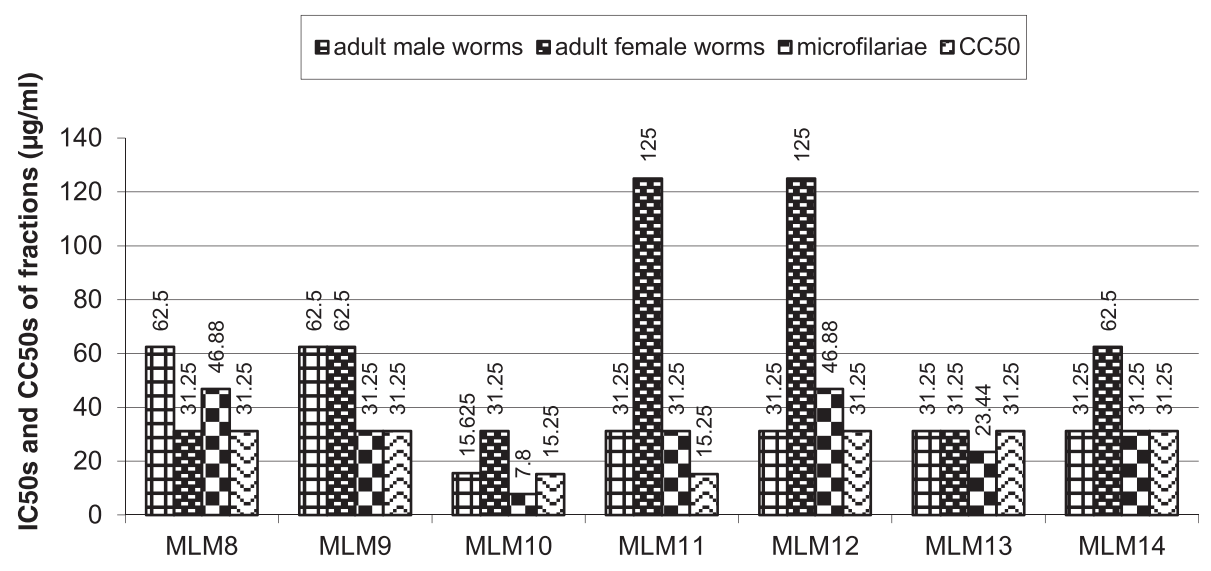

Most active fractions of ML leaves

Figure $5 \mathrm{IC}_{50 \text { s }}$ and $\mathrm{CC}_{50 \text { s }}$ of active fractions of $M$. lucida on mfs, adult worms and LLCMK2 cells. 


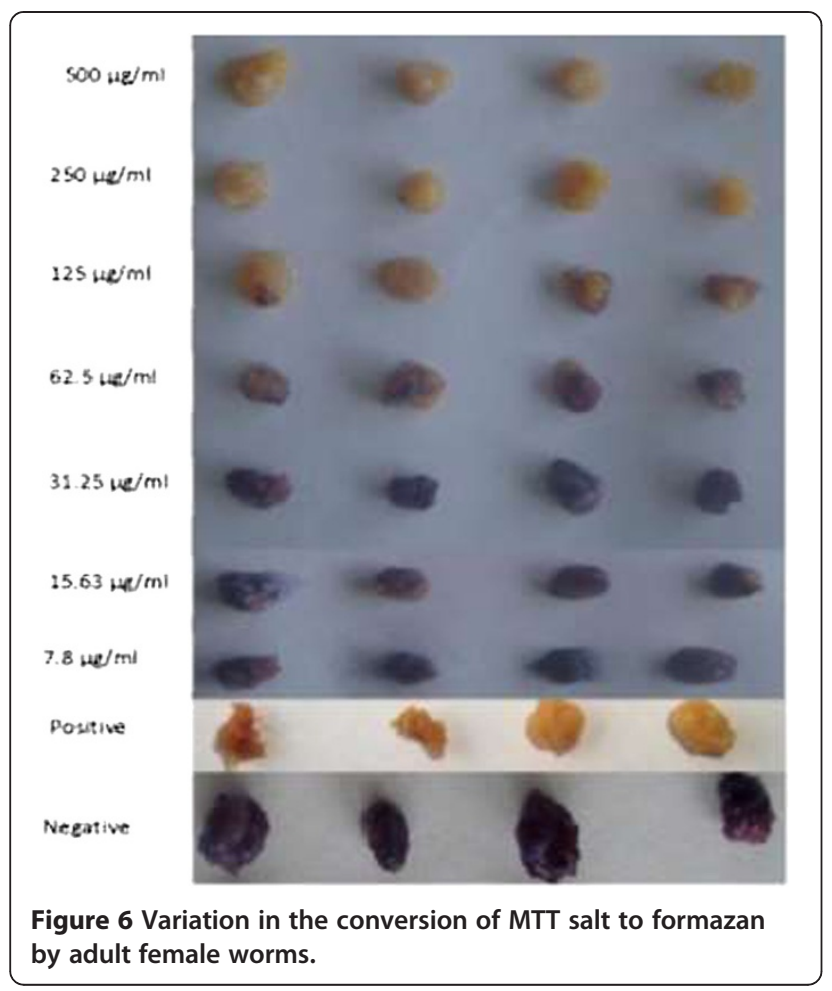

extracts were greater than that of ivermectin. All the animals for acute toxicity were monitored daily for changes in physical activities and appearance. Immediately following administration of the test substances, the animals displayed signs of discomfort and feebleness which lasted only for few minutes. By the first observation (30 minutes after dosing), the animals were already agile. For the fourteen days study period, none of the dosed mice died. When compared with their normal controlled counterparts, the intake of food and water was the same. There was daily regular agility. No change was observed in the physical activities and behavior in the test animal. Additionally, there was no loss of fur, no change in skin and mucous membrane. Visibly, the test and controlled groups were indistinguishable from one another on basis of their appearances and physical activity at the end of the 14 days study period.

\section{Phytochemical constituents of most active fractions}

Only fraction MLM14 from M. lucida showed a positive test for alkaloids. On the other hand, sterols were present in all the active fractions of $C$. laurinum as well as fractions MLM13 and MLM14 of M. lucida (Table 4).

\section{Discussion}

The primary aim of this study was to search in medicinal plants for new filaricidal compounds that might serve as drug leads. From ethnobotanical survey, two plants, C. laurinum and M. lucida from the same family
(Rubiaceae) were selected for study. Traditional health practitioners in Finge, a small community in North West Cameroon with high prevalence of onchocerciasis use C. laurinum to manage the ailment. This plant showed activity when screened in vitro against the bovine form of the parasite, $O$. ochengi which is the closest relative to the human form, O. volvulus. Based on the results obtained with $C$. laurinum, we decided to extend the study using a different member of the family, M. lucida gotten from the foot of Mount Cameroon (a different ecological setting). The results obtained from this study revealed the presence of filaricidal activities in the two plants that were obtained from two different geographical regions. In separate studies, both plants have been reported to show activites against Trypanosoma brucei brucei, a range of bacterial species, Leishmania major and P. falciparum [24-26,36]. Other studies carried out with Carapa procera, Polyalthia suaveolens [21], Piliostigma thonningii, Ocimum gratissimum, Nauclea latifolia and Alstonia boonei [37], Homalium Africanum [22], Annona senegalensis, Anogeissus leiocarpus, Euphorbia hirta, Parquetina nigrescens and Khaya senegalensis [23] have demonstrated anti-Onchocerca and anthelmintic activities.

The methanolic extracts of the leaves were the most active of both plants. Traditionally, C. laurinum concoction is prepared by boiling the leaves of the plant in water. Thereafter, a glass $(\sim 200 \mathrm{ml})$ of the resulting liquid is drunk three times a day for upto one month depending on manifested signs and symptoms. The highest activity recorded by the methanolic extracts partly justifies the efficiency of this method of preparation of the traditional regimen although the traditional preparations are hardly standardized. In a different study [22], the non-polar extracts of Homalium africanum were shown to be more active than the polar extracts. Although studies have shown that non-polar compounds such as essential oils are nematocidal [38], we herein demonstrate the nematocidal property of some polar extracts. Ndjonka and others reported similar findings in which the ethanolic extract from the leaves of Annona senegalensis killed $O$. ochengi worms [23]. Significant differences were observed in the $\mathrm{IC}_{50 \text { s }}$ of the crude extract and their fractions. The $\mathrm{IC}_{50 \mathrm{~s}}$ of C. laurinum crude extract on $\mathrm{mfs}$ were $93.75 \mu \mathrm{g} / \mathrm{ml}$ and $15.625 \mu \mathrm{g} / \mathrm{ml}$ respectively, for the crude extract and fraction $\mathrm{G}$ (fraction with highest activity). The same observation was seen with M. lucida extract which had $\mathrm{IC}_{50 \mathrm{~s}}$ of $62.5 \mu \mathrm{g} / \mathrm{ml}$ and $7.8 \mu \mathrm{g} / \mathrm{ml}$ for its crude extract and most active fraction (MLM 10) respectively. In like manner, $\mathrm{IC}_{50 \mathrm{~s}}$ of adult worms varied considerably with the derived fractions and the stock crude extracts. For both plants, the $\mathrm{IC}_{50 \mathrm{~s}}$ of the most active fractions were at least three fold lower than that of the extract. At present, we are investigating and characterizing the bioactive compounds responsible 
a $\rightarrow-C \rightarrow-D \rightarrow E \rightarrow F \rightarrow G \rightarrow-H$

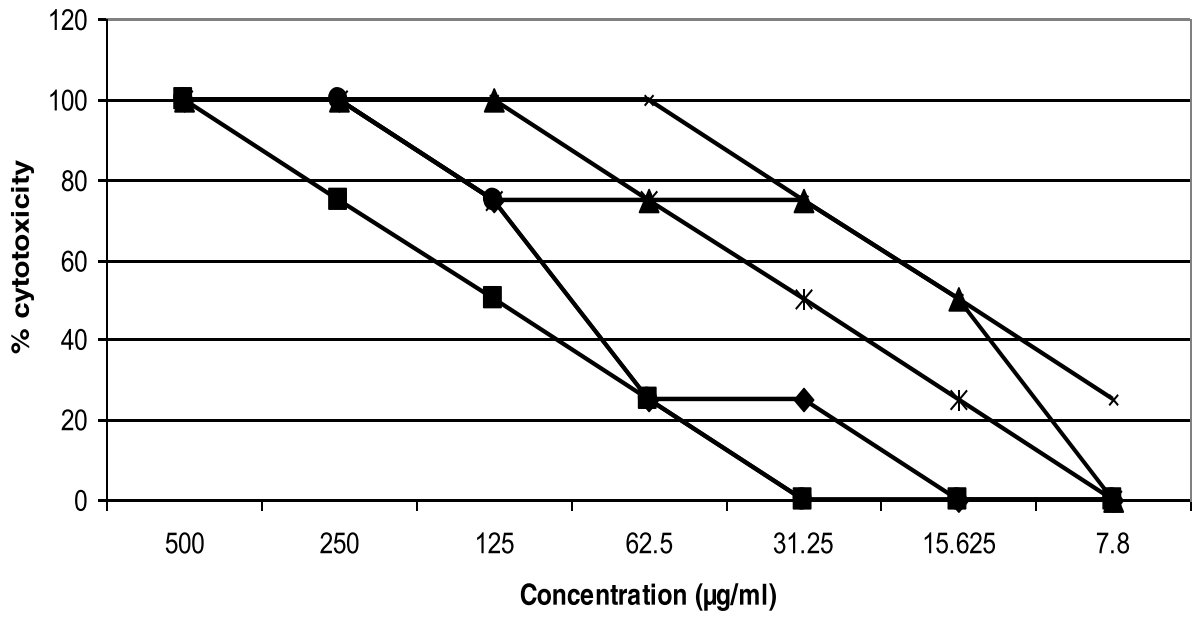

b
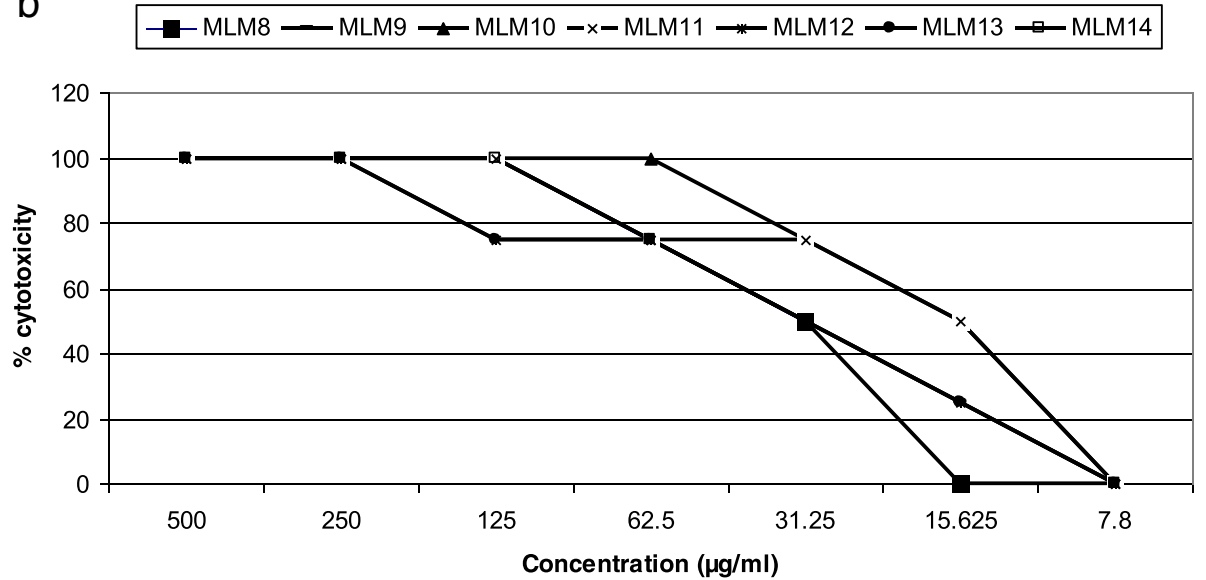

Figure $7 \%$ cytotoxicity of most active fractions of C. laurinum (a) and M. lucida (b) on LLCMK2 cells.

for the observed filaricidal activity. It is likely that following purification, some compounds will be obtained that will demonstrate activity that is higher than those gotten from their fractions.

Activity varied between the stages of the parasite and the extract/fraction used. While some extracts/fractions exerted more activity on the male adult worms, some showed more activity on the female and others still demonstrated more efficiency only on the mfs. The fractions also demonstrated a dose- and time-dependent activity with efficacy increasing when the dose was increased and the time of incubation also extended. Discrepancy

Table 4 Phytochemical analysis of the most active fractions

\begin{tabular}{|c|c|c|c|c|c|c|c|c|c|c|c|}
\hline \multirow[b]{2}{*}{ Active substance } & \multicolumn{6}{|c|}{ Most active fractions from $C$. laurinum } & \multicolumn{5}{|c|}{ Most active fractions from $M$. lucida } \\
\hline & $\bar{C}$ & D & $\mathrm{E}$ & $F$ & G & $\mathrm{H}$ & MLM9 & MLM10 & MLM11 & MLM13 & $\overline{\text { MLM14 }}$ \\
\hline Alkaloids & - & - & - & - & - & - & - & - & - & - & + \\
\hline Sterols & + & + & + & + & + & + & + & - & - & + & + \\
\hline Triterpenes & - & - & - & - & - & - & - & + & + & - & - \\
\hline Saponins & - & - & - & - & - & - & - & - & - & - & + \\
\hline Tannins & - & - & - & - & - & - & - & - & - & - & - \\
\hline Flavonoids & - & - & - & - & - & - & + & - & - & + & + \\
\hline
\end{tabular}


in activity between the various stages of the parasite probably indicates a variation in the target of the different extracts. However, all the extracts/fractions that were either active or moderately active on adult worm also showed activity on microfilariae. The reverse was not always true. This juvenile form of the parasite is apparently more susceptible to the extracts than their adult worm counterpart. Ivermectin exerts a similar selective effect. One fraction from C. laurinum (fraction E) had the same $\operatorname{IC}_{50}(62.5 \mu \mathrm{g} / \mathrm{ml})$ for all the three forms of the parasite. This was in contrast to the rest of the fractions where $\mathrm{IC}_{50 \mathrm{~s}}$ for $\mathrm{mfs}$ were generally lower than $\mathrm{IC}_{50 \mathrm{~s}}$ of adult worms. These interesting findings give more optimisms in the Onchocerca drug search as the drug of choice for the treatment of onchocerciasis should be one that possesses both macro-/microfilaricidal activity.

The studied plants showed no overt toxicity in laboratory mice. Regular food and water intake by all the mice was not hampered during the fourteen day period of follow-up. The apparent weakness and discomfort noticed immediately after dosing was probably a result of shock that came about by the consecutive use of $70 \%$ alcohol (for disinfecting the site of administration) and injection. Contrary to this observation, the most active extracts/fractions were apparently cytotoxic to LLCMK2 cells in the in vitro assay. The SI values for both the methanolic extracts of $M$. lucida and C. laurinum were $1.52 \mu \mathrm{g} / \mathrm{ml}$ and $2.67 \mu \mathrm{g} / \mathrm{ml}$ respectively while that of the control drug; ivermectin was $1 \mu \mathrm{g} / \mathrm{ml}$. This finding suggests that cytotoxicity of an extract/compound might not necessarily imply in vivo toxicity. This finding is consistent with the observations on Homalium africanum and Margaritaria discoidea [22]. A detoxification mechanism may account for this in vivo observation and also partly justifies the absence of adverse effects in patients who take the concoction for therapy.

\section{Conclusion}

This study has revealed the anti-Onchocerca activities of extracts of M. lucida and C. laurinum, indicating a possible new source for developing a phytomedicine or drug for the treatment of the disease. It also validates the use of C. laurinum by traditional health practitioners in the management of the disease in rural areas where onchocerciasis is prevalent.

\section{Competing interests}

The authors declare that they have no competing interests.

\section{Authors' contributions}

MS designed the experiments, collected the plants, prepared the extracts, performed the experiments, analyzed the results, and drafted the manuscript. $\mathrm{JM}$ prepared the extracts and performed the experiment. JM prepared the extracts, analyzed and interpreted the data. BN prepared the extracts, analyzed and interpreted the data. FCN did the conception, design the experiments, supervised the experiments and drafted the manuscript. All authors read the manuscript, contributed in correcting it, and approved its final version.

\section{Acknowledgement}

This investigation received part financial assistance from the UNICEF/UNDP/ World Bank/WHO Special Programme for Research and Training in Tropical Diseases (TDR) (Project A70107).

\section{Author details}

${ }^{1}$ Department of Biomedical Sciences, Faculty of Health Sciences, University of Bamenda, PO Box 39, Bambili, Cameroon. ${ }^{2}$ Department of Biochemistry and Molecular Biology, Faculty of Science, University of Buea, P.O. Box 63, Buea, Cameroon. ${ }^{3}$ Department of Chemistry, Faculty of Science, University of Buea, P.O. Box 63, Buea, Cameroon.

Received: 9 January 2014 Accepted: 27 August 2014

Published: 1 September 2014

\section{References}

1. Burbelo PD, Leahy HP, Ladarola MJ, Nutman TB: A four-antigen mixture for rapid assessment of Onchocerca volvulus infection. PLoS Negl Trop Dis 2009, 3(5):e438.

2. Gustarven K, Hopkins A, Sauerbrey M: Onchocerciasis in the Americas: from arrival to (near) elimination. Parasit Vectors 2011, 4:205.

3. Kale OO: Onchocerciasis: the burden of the disease. Ann Trop Med Parasit 1998, 92(1):101-115.

4. Taylor HR, Tripis M, Cupp EN, Brotman B, Newland HS, Soboslay PT, Greene BM: Ivermectin prophylaxis against experimental Onchocerca volvulus infection in chimpanzees. Am J Trop Med Hyg 1988, 39:86-90.

5. Burnham G: Onchocerciasis. Lancet 1998, 351:1341-1346.

6. WHO (World Health Organisation): Expert committee on onchocerciasis control. Onchocerciasis and its control. Report of the WHO committee on onchocerciasis. WHO Tech Rep Ser 1995, 852:752-767.

7. WHO (The World Health Organization): Onchocerciasis (River blindness). WHO; 2000. Fact sheet Nº 095.

8. Tropical Disease Research (TDR): Onchocerchiasis, TDR Seventeenth Programme Report: Progress 2003-2004; 2005:44-49. TDR/GEN/05.1.

9. Diawara L, Traoré MO, Badji A, Bissan Y, Doumbia K, Goita SF, Konaté L, Mounkoro K, Sarr MD, Seck AF, Toé L, Tourée S, Remme JHF: Feasibility of onchocerciasis elimination with ivermectin treatment in endemic foci in Africa: first evidence from studies in Mali and Senegal. PLoS Negl Trop Dis 2009, 3(7):e497.

10. Cupp EW, Sauerbrey M, Richards F: Elimination of human onchocerciasis: history of progress and current feasibility using ivermectin (Mectizan ${ }^{\circledR}$ ) monotherapy. Acta Trop 2011, 120:S100-S108.

11. Boussinesq M, Gardon J, Gardon-Wendel N, Kamgno J, Ngoumou P, Chippaux JP: Three probable cases of Loa loa encephalopathy following ivermectin treatment for onchocerciasis. Am J Trop Med Hyg 1998, 58(4):461-469.

12. Esum M, Wanji S, Tendongfor $N$, Enyong P: Co-endemicity of loiasis and onchocerciasis in the South West Province of Cameroon: implications for mass treatment with ivermectin. Trans R Soc Trop Med Hyg 2001, 95(6):673-676.

13. Awadzi K, Boakye DA, Edwards G, Opoku NO, Attah SK, Osei-Atweneboana MY, Lazdins-Helds JK, Ardrey AE, Addy ET, Quartey BT, Ahmed K, Boatin BA, Soumbey-Alley EW: An investigation of persistent microfilaridermias despite multiple treatments with ivermectin, in two onchocerciasis-endemic foci in Ghana. Ann Trop Med Parasit 2004, 98(3):231-249.

14. Awadzi K, Attah SK, Addy ET, Opoku NO, Quartey BT, Lazdins-Helds JK, Ahmed K, Boatin BA, Boakye DA, Edwards G: Thirty month follow-up of sub-optimal responders to multiple treatments with ivermectin, in two onchocerciasis-endemic foci in Ghana. Ann Trop Med Parasitol 2004, 98:359-370.

15. Bourguinat C, Pion SDS, Kamgno J, Gardon J, Duke BOL, Boussinesq M, Prichardet RK: Genetic selection of low fertile Onchocerca volvulus by ivermectin treatment. PLoS Negl Trop Dis 2007, 1(1):e72.

16. Lustigman S, McCarter JP: Ivermectin resistance in Onchocerca volvulus: toward a genetic Basis. PLoS Negl Trop Dis 2007, 1(1):e76.

17. Ates DA, Erdogrul OT: Antimicrobial activities of various medicinal and commercial plant extracts. Turk J BioL 2003, 27:157-162.

18. WHO (The World Health Organization): Traditional Medicine. WHO; 2003. Fact sheet $\mathrm{N}^{\circ} 134$

19. Nisha M, Kalyanasundaram M, Paily KP, Abidha VP, Balaraman K: In vitro screening of medicinal plant extracts for macrofilaricidal activity. Parasitol Res 2007, 100(3):575-579. 
20. Titanji VPK, Ayafor JP, Muluh JP, Mbacham WF: In vitro killing of Onchocerca volvulus (Filaroidea) adults and microfilariae by selected Cameroonian medicinal plant extracts. Fitoterapis 1987, VIII(5):338-339.

21. Titanji VPK, Evehe MS, Ayafor JF, Kimbu SF: Novel Onchocerca volvulus filaricides from Carapa procera, Polyalthia suaveolens and Pachypodanthium staudtii. Acta Leiden 1990, 59:377-382.

22. Cho-Ngwa F, Abongwa M, Ngemenya NM, Nyongbela KD: Selective activity of extracts of Margaritaria discoidea and Homalium africanum on Onchocerca ochengi. BMC Complement Altern Med 2010, 10:62.

23. Ndjonka D, Agyare C, Lüersen K, Djafsia B, Achukwi D, Nukenine EN, Hensel A, Liebau E: In vitro activity of Cameroonian and Ghanaian medicinal plants on parasitic (Onchocerca ochengi) and free-living (Caenorhabditis elegans) nematodes. J Helminthol 2011, 85(3):304-312.

24. Nweze El, Okafor JI, Njoku O: Antimicrobial activities of methanolic extracts of Trema guineensis (Schumm and Thorn) and Morinda lucida benth used in Nigerian. Biol Res 2004, 2(1):39-46.

25. Koroma L, Ita BN: Phytochemical compounds and antimicrobial activity of three medicinal plants (Alchornea hirtella, Morinda geminata and Craterispermum laurinum) from Sierra. Afr J Biotechnol 2009, 8(22):6397-6401.

26. Koumaglo K, Gbeassor M, Nikabu O, de Souza C, Werner W: Effects of three compounds extracted from Morinda lucida on Plasmodium falciparum. Planta Med 1992, 58(6):533-534.

27. Asuzu IU, Chineme CN: Effects of Morinda lucida leaf extract on Trypanosoma brucei brucei infection in mice. J Ethnopharmacol 1990, 30(3):307-313.

28. Olajide OA, Awe SO, Makinde JM, Morebise O: Evaluation of the Anti-diabetic Property of Morinda lucida Leaves in Streptozotocin-diabetic Rats. J Pharm Pharmacol 1999, 51:1321-1324.

29. Mccall JP, Townson H, Trees AJ: Morphometric differentiation of the Onchocerca volvulus and O. ochengi infective larvae. Trans Roy Soc Med Hyg 1992, 86:63-65.

30. Comley JC, Townson S, Rees MJ, Dobinson A: The application of MTT-formazan colorimetry studies on filarial worm viability. Trop Med Parasitol 1989, 40:311-316.

31. Townson S, Tagboto S, McGarry HF, Egerton GL, Taylor MJ: Onchocerca parasites and Wolbachia endosymbionts: evaluation of a spectrum of antibiotic types for activity against Onchocerca gutturosa in vitro. Filaria J 2006, 5:4.

32. EEC (European Economic Community): Council Directive 86/609/EEC of 24 November 1986 on the approximation of laws, regulations and administrative provisions of the member states regarding the protection of animals used for experimental and other scientific purposes. Brussels, Belgium: European Economic Community; 1986.

33. Kilkenny C, Browne WJ, Cuthill IC, Emerson M, Altman DG: Improving bioscience research reporting: the ARRIVE guidelines for reporting animal research. PLoS Biol 2010, 8(6):e1000412.

34. OECD/OCDE 420: OECD Guideline for Testing of Chemicals. ; 2001

35. Trease GE, Evans WC: Pharmacognosy. 13th edition. Brailliar Tiridel Can: Macmillan publishers; 1989:11.

36. Sittie AA, Lemmich E, Olsen CE, Hviid L, Kharazmi A, Nkrumah FK, Brøgger CS: Structure-activity studies: In vitro antileishmanial and antimalarial activities of anthraquinones from Morinda lucida. Planta Med 1999, 65(3):259-261.

37. Fakae BB, Campbell AM, Barrett J, Scott IM, Teesdale-Spittle PH, Liebau E, Brophy PM: Inhibition of glutathione S-transferases (GSTs) from parasitic nematodes by extracts from traditional Nigerian medicinal plants. Phytother Res 2000, 14(8):630-634

38. Fekam BF, Makougoum MH, Ayong LS, Wembe FE, Tume BC, Amvam ZPH, Townson S, Ngu JL: Preliminary investigation of the filaricidal activities of five essential oils on Onchocerca ochengi. Chemical Sciences 2001, Ayafor Memorial Symposium.

doi:10.1186/1472-6882-14-325

Cite this article as: Samje et al.: In vitro anti-Onchocerca ochengi activities of extracts and chromatographic fractions of Craterispermum laurinum and Morinda lucida. BMC Complementary and Alternative Medicine 2014 14:325.

\section{Submit your next manuscript to BioMed Central and take full advantage of:}

- Convenient online submission

- Thorough peer review

- No space constraints or color figure charges

- Immediate publication on acceptance

- Inclusion in PubMed, CAS, Scopus and Google Scholar

- Research which is freely available for redistribution

Submit your manuscript at www.biomedcentral.com/submit
C Biomed Central 